\title{
SYMPTOMATIC ENDOMETRIOSIS OF RECTUS ABDOMINIS MUSCLE IN A PATIENT WITH UTERUS DIDELPHYS
}

\author{
Yavuz Emre SUKUR, Murat GOZUKUCUK, Korhan KAHRAMAN, Serife Esra CETINKAYA, Murat SONMEZER \\ Department of Gynecology and Obstetric, Ankara University, Faculty of Medicine, Ankara, Turkey
}

\begin{abstract}
SUMMARY
Background: Endometriosis of the rectus abdominis muscle is a very rare event and it should be kept in mind in the differential diagnosis of women with abdominal wall mass.

Case: 42 year-old G2 P2 patient with uterus didelphis was referred with a painful abdominal wall mass of approximately $4 \times 5 \mathrm{~cm}$ size. The mass that has contrast matter enhancement on CT was excised with median laparotomy below the umbilicus. The mass which was thought as endometriosis was excised without remaining any pieces to prevent recurrence and primarily repaired.

Discussion: Along with the increasing incidence due to increased cessarean rates the endometrial wall endometriosis is an important diagnosis that should not be omitted. The treatment is surgical resection and to we should take care not to leave any pieces to prevent recurrence especially when it is located atypically.
\end{abstract}

Key words: cesarean section, endometriosis, rectus abdominis muscle

Journal of Turkish Society of Obstetrics and Gynecology, (J Turk Soc Obstet Gynecol), 2012; Vol: 9 Issue: 1 Pages: 80- 3

\section{UTERUS DIDELFISII OLAN OLGUDA REKTUS ABDOMINIS KASINDA SEMPTOMATIK ENDOMETRIOZIS}

\section{ÖZET}

Giriş: Rektus abdominis kasında endometriozis oldukça ender rastlanan ve kadınlarda karın duvarı kitlelerinin ayırıcı tanisinda dikkat edilmesi gereken bir durumdur.

Olgu: 42 yaşında G2 P2, uterus didelfisi olan hasta karın duvarında yaklaşık $4 x 5 \mathrm{~cm}$ 'lik hassas kitle nedeniyle başvurdu. BT'de kontrast madde tutulumu olan kitle umbilikus altı median kesi ile eksize edildi. Operasyonda endometriozis odă̆ı olduğu fark edilen kitle geride rekürrense yol açacak parça kalmayacak şekilde çıkartıldı ve primer onarim yapildl.

Tartışma: Artan sezaryen oranlarıla birlikte insidansının artacağı düşünüldüğünde abdominal duvar endometriozisi atlanmamasl gereken önemli bir teşhistir. Tedavisi cerrahi rezeksiyondur ve özellikle atipik yerleşimli olduğunda rekürrensi engellemek için geride odak bırakmamaya özen gösterilmelidir.

Anahtar kelimeler: endometriozis, rektus abdominis kasl, sezaryen

Türk Jinekoloji ve Obstetrik Derneği Dergisi, (J Turk Soc Obstet Gynecol), 2012; Cilt: 9 Sayl: 1 Sayfa: 80- 3

Address for Correspondence: Yavuz Emre Şükür. Kıbrıs cad. no: 9a/5 Kurtuluş, Çankaya, 06600 Ankara

Phone: + 90 (533) 2409381

e-mail: yesukur@yahoo.com

Received: 15 December 2010, revised: 15 February 2011, accepted: 09 March 2011, online publication: 08 December 2011 


\section{INTRODUCTION}

Endometriosis is defined as the ectopic localization of normal endometrial tissue outside the endometrial cavity and uterine musculature ${ }^{(1)}$. The pelvis is the most common site of this reproductive age disease but, endometriotic implants may occur nearly anywhere in the body such as central nervous system, lungs, kidneys, extremities, skin and abdominal wall. Endometriosis of the rectus abdominalis muscle is a very rare event and it should be kept in mind in the differential diagnosis of women with abdominal wall mass. Almost all of the rectus abdominalis muscle endometriosis originate from the scar of previous surgery ${ }^{(2)}$. The incidence in post cesarrean population is $0,45 \%(3)$. Here in, a patient with uterine didelphis who had endometriosis in rectus abdominalis muscle is reported.

\section{CASE}

42 years old G2 P2 patient was admitted with a left abdominal wall mass which was present for the last 7 years and growing for the last 2 years. She complained of pain and size increment of the mass during the menstrual period. She had two births via cesarean section 17 and 19 years ago. Her gynecological examination was normal. Transvaginal sonography revealed no significant pathology. At physical examination a 4x5 $\mathrm{cm}$ sized, painfull mass was determined at the left lower quadrant of abdominal wall.

Abdominal-pelvic computerized tomography (CT) revealed a fusiform thickening and contrast matter enhancement at the left rectus muscle (Figure 1). Pelvic magnetic resonance imaging (MRI) revealed fusiform thickening and pathologic contrast matter enhancement at both rectus abdominalis muscles which was significant at the left side. This lesion was concluded as fibromatosis or hematoma. Due to the borderline increase in CA-125 level (26,3 U/ml [0-21 U/ml]) and cyclic increment of pain and size of the mass endometriosis was thought primarily at the differential diagnosis.

At the operation with midline incision the mass was diagnosed as an endometriotic focus. The mass was excised with no recurrence and the rectus muscle was primarily sutured. The pathology of the mass was reported as endometriosis externa and the patient was discharged without complications in the postoperative second day.

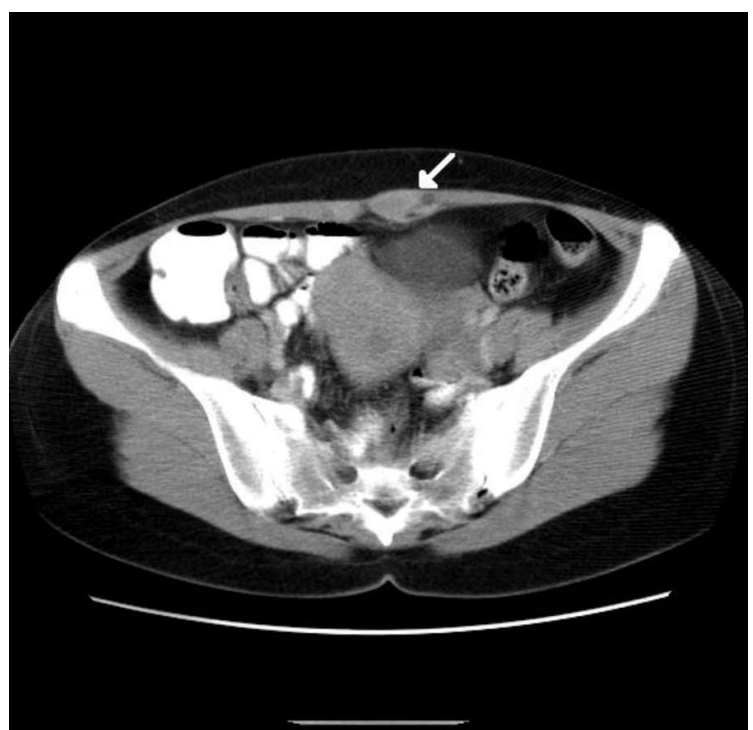

Figure 1: Abdominal-pelvic computerized tomography image. Fusiform thickening and contrast matter enhancement at the left rectus abdominalis muscle (arrow).

\section{DISCUSSION}

Endometriosis is a benign disease in which the endometrial glands and stroma locate ectopically outside the uterus and causes pelvic pain and infertility. The incidence is $3-10 \%$ in reproductive age women ${ }^{(4)}$. Although the pelvis is the primary site, endometrial cells can proliferate in any part of the body such as central nervous system, lungs, pleura, heart, diaphragm, urinary bladder, liver, gastrointestinal system, umbilicus, abdominal wall, biceps muscle, bone tissue and peripheral nerves ${ }^{(5)}$. However, abdominal wall endometriosis is an uncommon condition $(1,6)$.

Although the mechanism of endometriosis is not known exactly, presence of multifactorial interactions is supposed(7). One of the most accepted theories is retrograde menstruation ${ }^{(8)}$. According to this theory the endometrial cells implant to the pelvic wall and cause bleeding and increase in size in response to the hormonal stimulation. However, the presence of endometriotc foci in organs such as lung, eye, nose and even in male patients under estrogen treatment weakens this theory ${ }^{(7)}$. Another is the coelomic metaplasia theory in which the peritoneal epithelium is transformed to the endometrial epithelium due to the inflammatory factors. According to this theory coelomic epithelium is responsible from the generation of both the endometrial and peritoneal epithelia and these cells can be transformed to each other. According 
to another theory mullerian remnants can transform to endometrial tissues and response to the hormonal stimuli. However, according to the vascular theory endometrial cells can spread via lymphatic and blood vessels. In this case retrograde menstruation and vascular theories are both acceptable.

Development of endometriosis is also suggested with a reproductive organ abnormality $(1,9)$. Endometriosis together with uterus didelphis is reported in adolescents with unilateral vaginal pouch and cervical agenesis $(9,10)$. Also in our patient, such a predisposing factor for retrograde menstruation is possible.

Although the presence of ectopic endometrial tissue in abdominal wall is frequently secondary to previous surgery, it was also reported in a case without previous surgery ${ }^{(1)}$. Rectus abdominalis muscle endometriosis is an uncommon condition and Coley was the first to report it in 1993(11). Surgical scar endometriosis can occur due to the iatrogenic transfer of endometrial cells (12). It can be seen after cesarean section, appendectomy, episiotomy and histerectomy. Surgical scar endometriosis is not so common and the incidence is $1 \%$. But it's incidence is thought to be higher than its suggested(13). Endometriosis can occur 1-20 years after the surgery (mean 4,8 years) $^{(14)}$.

Abdominal wall endometriosis is difficult to diagnose. The differential diagnoses of surgical scar masses include abscess, hematoma, lipoma, suture granuloma, sarcoma, endometriosis, desmoids tumor, lymphoma and metastatic disease ${ }^{(3)}$. The symptoms of abdominal wall endometriosis are pain at the surgical incision, tender mass and cyclic pain related to the menstrual cyclus $(3,5)$. Cyclic bleeding from the mass is also possible (5). It's thought pathognomonic for endometriosis when these symptoms are focally related to an incision scar (14). As is present in this case, when the growing mass is limited in the rectus abdominalis muscle, pain becomes the primary symptom because of the pressure on rectus abdominalis muscle sheets. Imaging thecniques are helpful, but not enough for the definitive diagnosis. Although there are no specific ultrasonographic findings for endometriosis, ultrasonographic fine needle aspiration and clinical story are valuable at diagnosis $(6,15)$. CT and MRI can be used to define the localization of solid masses. MRI is superior to CT as it can define the hemorrhagic lesions of surgical scar endometriosis more easily and earlier. However, the definitive diagnosis of abdominal wall endometriosis is biopsy(16).

The treatment of abdominal wall endometriosis is the excision of the mass. According to Koger et al. the incidence of recurrence is low in patients treated by wide excision $^{(14)}$. Due to the adhesions of these lesions, partial fascial resection and synthetic mesh grafting may be required ${ }^{(3)}$.

In conclusion, abdominal wall endometriosis is one of the first diagnoses for incision scar masses which cause cyclic pain. The incidence is suggested to be increased with the increasing cesarean section ratio. So, the diagnosis of abdominal wall endometriosis should be kept in mind in the presence of a predisposing factor such as uterus didelphis. The treatment should be surgical excision with no rest to prevent local recurrences.

\section{REFERENCES}

1. Tomas E, Martin A, Garfia C, Sanchez Gomez F, Morillas JD, Castellano TG, et al. Abdominal wall endometriosis in absence of previous surgery. J Ultrasound Med 1999; 18: 3734

2. Chun JT, Nelson HS, Maull KI. Endometriosis of the abdominal wall. Southern Med J 1990; 83: 1491- 2.

3. Dwivedi AJ, Agrawal SN, Silva YJ. Abdominal wall endometriomas. Digestive Dis Sci 2002; 47: 456- 61 .

4. Speroff L, Fritz MA. Endometriosis. In: Speroff L, Fritz MA. Clinical Gynecologic Endocrinology and Infertility. Seventh edition LWW, W Kluwer Co.; 2005. p.1103- 33.

5. Jubanyik KJ, Comite F. Extrapelvic endometriosis. Endometriosis 1997; 24: 411- 40 .

6. Dirican A, Ünal B, Özgör D, Ünal D, Işık D, Iş1k B, et al. Rektus abdominus kasında endometriozis: olgu sunumu. İnönü Üniv Tıp Fak Derg 2008; 15: 55- 7.

7. Wellbery C. Diagnosis and treatment of endometriosis. Am Fam Physician 1999; 60: 1753- 62.

8. Thomas EJ. Diagnosis and treatment of endometriosis. Am Fam Physician 1999; 60: 1753- 68.

9. Sanfilippo JS, Wakim NG, Schikler KN, Yussman MA. Endometriosis in association with uterine anomaly. Am J Obstet Gynecol 1986; 154: 39- 43.

10. Yang CC, Tseng JY, Chen P, Wang PH. Uterus didelphys with cervical agenesis associated with adenomyosis, a leiomyoma and ovarian endometriosis. J Reprod Med 2002; 47: 936- 8.

11. Coley BD, Casola G. Incisional endometrioma involving the 
rectus abdominis muscle and subcutaneous tissues: CT appearance. AJR 1993; 160: 549- 50.

12. Kır Şahin F, Şahin DA, Köken G, Koşar MN, Şahin Ö Sezaryen skarında endometriozis olgusu ve literatürün gözden geçirilmesi. İst Tıp Fak Derg 2006; 69: 117- 9.

13. Wolf GC, Singh KB. Cesarean scar endometriosis: areview. Obstet Gynecol Surv 1989; 44: 89- 95.
14. Koger K, Shatney CH, Hodge K, et al: Surgical scar endometrioma. Surgery, Gynecology and Obstetrics 1993; 177: 243- 6.

15. Wolf C. Sonographic features of abdominal wall endometriosis. AJR 1997; 169: 916

16. Balleyguier C, Chapron C, Chopin N, Helenon O, Menu Y. Abdominal wall and surgical scar endometriosis: magnetic resonance imaging. Gynecol Obstet Invest 2003; 55: 220- 4. 